\title{
Teachers' science camp experiences in southern Chile: Strengthening teacher identity and continuing education
}

\author{
Marta Silva ${ }^{1}$, Michel Parra ${ }^{2}$, Ronnie Reyes-Arriagada ${ }^{3}$ and Jennifer Brito ${ }^{1}$ \\ ${ }^{1}$ Universidad Austral de Chile, Chile \\ ${ }^{2}$ Universidad de Chile, Chile \\ ${ }^{3}$ PAR Explora Los Ríos, Universidad Austral de Chile, Chile
}

Science camps for teachers have been held in Chile for several years and are recognized as important opportunities for continuing education, but they have been largely ignored as instances for impactful reflection on teacher selfassessment and identity. This article presents the analysis of teacher experiences at a science camp held in southern Chile called "Explora Va!", which was designed not just as an instance for continuing education for teachers in scientific contents but also for individual and collaborative reflection aimed at strengthening educators' skills as agents of change in their institutions. The question of this study was: how do the participants represent their teacher identities based on their experiences at the "Explora Va!" Camp? Using a qualitative approach, the results of the analysis of narratives from teachers' camp journals are reported here. The narratives from these journals provide an account of two dimensions, personal and contextual, where the importance of the teaching profession and science teaching were explored beyond conventional disciplinary limits. Collaboration, innovation, and personal and professional growth at the camp served to signify and resignify professional identities based on common elements but attending to the particular circumstances and unique backgrounds of each teacher.
ARTICLE DETAILS
LUMAT General Issue Vol 9 No 1 (2021), 397-425
Received 25 August 2020
Accepted 24 May 2021
Published 4 June 2021
Pages: 29
References: 73
Correspondence:
marta.silva@uach.cl
https://doi.org/10.31129/ LUMAT.9.1.1398

Keywords: teachers' camp, science camp, continuing education, teachers' professional identity, teacher reflection

\section{Introduction}

In the initial and continuing education of teachers in Chile, little focus has been placed on activities that encourage processes of self-criticism and reflection on one's own teaching work. However, in recent years the Ministry of Education (MINEDUC) has provided guidelines aimed at strengthening teacher identity and professional trajectories, generating spaces for teachers to exercise the reflective process regarding their own educational practices.

In a recent evaluation of educational gaps and teaching skills in Chile, teachers obtained a very unsatisfactory assessment in the dimension of reflection on pedagogical practices (MINEDUC, 2020). In the Southern region of Los Ríos, it was reported that only $19 \%$ of teachers undertake analysis of the pedagogical strategies that they use, $27 \%$ propose adequate strategies, criteria, and assessment instruments, 
and only $18 \%$ formulate reflections that allow them to determine which learning outcomes have been achieved by students (MINEDUC, 2017). Meanwhile, data on teachers' perceptions of their working conditions and professional development indicate that a low percentage consider analytical reflection to be important in their work; however, this factor emerges as quite deficient in teacher evaluations and has been shown to strongly impact teacher identity (MINEDUC, 2017).

In this context, spaces for intensive continuing education for teachers (workshops, courses, skills training) have included educational experiences centered mainly on delivering curricular contents and pedagogical innovations to improve teachinglearning processes. However, these spaces could, in addition, provide a key opportunity to address fundamental dimensions of the teacher's role, such as strengthening professional identity and self-assessment, if they were also designed as instances of collaborative reflection.

In Chile, science camps for teachers have been held for several years as instances of informal continuing education; little attention has been given to how this format addresses reflection and the impact that it can have on factors such as the selfassessment and identity of educational professionals. Likewise, there is little understanding of how, in said spaces, the collaborative model of professional research can be developed, through the collaborative identification of problems, in order for teachers to question and reflect on their own practices and those of other participants with the aim of strengthening teacher identity (Kennedy, 2014).

The research question is: How do the participants represent their teacher identities based on their experiences at the "Explora Va!" Camp? The objective of this research is to describe and analyze the experience of a five-day science camp for science educators held in southern Chile, part of a program called "Explora Va!" Science Camps for Teachers. This camp was designed not just as an instance of teacher training in scientific contents but also as an opportunity for strengthening the competencies of educators as agents of change in their schools and generating personal and collective reflection. Employing a qualitative approach, the results reported here are based on the analysis of narratives from teacher journals, where participants recorded their experiences and reflections during the camp. 


\section{Theoretical framework}

\subsection{Continuing education for teachers}

The challenges that teachers face throughout their careers are many. In this context, continuing education for teachers represents a possibility to "develop individual abilities, knowledge, experience, and other characteristics as a teacher" (OECD, 2009).

The discourse encouraged in this area, especially at the government level and in public policy in education, holds that the improvement of teacher quality will positively impact the improvement of students (Kennedy, 2005). The continuing education of teachers is crucial to reach this objective (Kennedy, 2014).

In Latin America, the continuing education of teachers tends to be framed in a context of educational reforms and unfavorable work conditions for teachers, including low salaries and excessive workload. But teachers meet professional demands based on the concept of accountability to existing protocols and structures: "programs oriented at teacher development are inserted into antiquated systems in which norms and regulations tend to restrict the possibility of innovation" (Ávalos, 2004, p. 140). Thus, the results of continuing education programs for teachers are lessened when school realities are ignored and the knowledge, skills, and beliefs of teachers are not considered (Qablan et al., 2015).

Diverse studies (Fraser et al., 2007; Kennedy, 2005; Kennedy, 2014) point to distinct theoretical frameworks for analyzing models of continuing education for teachers. There are those related to teachers' personal situations-beliefs, interests, and motivations-and those related to social situations-the context in which the educational experience takes place, including feelings of support and favorable relationships between individuals and groups. Ultimately, a strong link should exist between theory and practice: intellectual stimulation and professional relevance.

The importance of professional reflection is well recognized, as it provides opportunities for the development of teachers' professional agency and control over their learning processes in order to achieve transformational learning (Fraser et al., 2007). Transformational models, as collaborative models of professional research, call for the collaborative identification of problems in order for teachers to inquire and reflect on their practice and that of others. These models have shown effectiveness in enacting educational change at individual, school, and system-wide levels (Kennedy, 2014). As the capacity for teachers' agency increases, so do their achievements in the 
development of professional autonomy. This stems from a democratic perspective that seeks for teacher motivation to emerge based on their interiority and identification with their role and for learning objectives to be articulated through their beliefs and values alongside the acquisition and application of new knowledge and abilities (Kennedy, 2014).

\subsection{Science camps as spaces of continuing education for teachers}

While the literature widely addresses camps as an informal learning strategy in the sciences, it tends to center on students' learning contents, with their teachers, in some cases, as participants alongside them (Logerwell, 2009; Luehmann \& Markowitz, 2007; Antink-Meyer et al., 2016; Barab \& Hay, 2001).

The majority of research on the effectiveness of science camps, offered for different purposes, has been carried out with participants from primary or secondary school (Karaman, 2016). In these studies, experiences influenced participants' attitudes, interests, and learning in science, both short- and long-term, yet while positive results have been demonstrated in terms of affective aspects, there is little evidence available on the impact of camps on cognitive aspects related to the learning of contents (Antink-Meyer et al., 2016).

Meanwhile, studies on camps for science teachers are scarce and focus on content. Jacoby (2013) describes a camp for science teachers as "training" where the teachers learn by "doing" in order to motivate their students to learn physics. A similar approach is offered by Post-Zwicker and Guilbert (1998), who describe a "Plasma Camp" designed to help secondary teachers carry out research and projects in the classroom.

Given the shortcomings of education in the sciences and the limited offering of associated programs (Aflalo, 2014; Backhus \& Thompson, 2006), professional development activities for working teachers could compensate for these deficiencies. Informal educational scenarios, such as science camps, constitute an ideal learning environment that permits participants to compensate for their lack of knowledge in the sciences (Fields, 2009; Foster \& Shiel-Rolle, 2011; Leblebicioglu et al., 2011; Spector et al., 2012), which is generally a product of their weak initial education in the area (Karaman et al., 2016).

The literature regarding the effectiveness of science camps for teachers is limited (Naizer et al., 2003; Wallace \& Brooks, 2014; Karaman et al., 2016), though it has been demonstrated that participants show significant progress in learning, 
independent of the discipline that they teach (Karaman et al., 2016). More research is required to examine the positive experiences of teachers in science camps as an important contribution to knowledge in this area of education (Karaman et al., 2016).

\subsection{Continuing education and teacher identity}

Ruohotie-Lyhty (2018) states that teachers' agency is linked to their identity narrative. This is true, firstly, because their professional path is underpinned by selfperceptions of their role and labor based on what they expect, believe, and value in their work. Secondly, narrative activities allow them to organize and give meaning to their experiences, constituting a process of agency using their individual experiences and the interrelationships of educational communities.

In Chile, research related to the concept of teacher identity has awoken a growing interest in the topic since the 1990s. This construct refers to how teachers experience their work subjectively, as well as the perception of the profession held by their colleagues and the rest of society.

While the conceptual notion of professional identity has generated strong and growing interest within academia (De Tezanos, 2012), a shared definition does not yet exist for this idea, with distinct definitions and understandings present in the literature and utilized in different manners in the educational sphere.

A bibliographic review of the construct carried out by Beijaard et al. (2004) pioneered the systematization of research principals in the area of teachers' professional identity, reviewing 22 articles published between 1988 and 2000 in order to determine which characteristics are essential to research on teachers' professional identity, how current research can be characterized, and what problems need to be raised when studying this topic. Among the most important characteristics, the authors highlight that it is a continuous process of interpretation and reinterpretation of experiences; it entails the person and their context; it contains sub-identities; and it points to the centrality of agency, with reference to the need for teachers to be active in the process of professional development. Ultimately, the review concludes that in the majority of studies, the concept is defined differently, or that a clear definition of teachers' professional identity is not present.

Beijaard et al. (2004) also contend that in the definition of teachers' professional identity, the majority of studies emphasize the personal sphere, with an underestimation of the contextual, which also plays a role in identity formation. Thus, in the formation of teacher identity there exists a constant tension between agency 
(the personal dimension of teaching) and structure (what is socially rendered), translating as a complex equilibrium and dynamic in which self-image is balanced with a variety of roles that teachers feel they must play (Volkmann \& Anderson, 1998).

Teachers' professional identity forms part of the social identity of an individual as well as the self-definition that each teacher creates of their person. Beyond the multiple considerations involved in attempting to characterize teacher identity, consensus exists on the fact that it is not a stable entity but rather a process subject to continuous change and construction of meaning and interpretation. Likewise, there is general agreement that teacher identity is influenced by previous experiences, the personal characteristics of the individual, and professional contexts (Beauchamp \& Thomas, 2009; Beijaard et al., 2004; Flores \& Day, 2006; Hong, 2010; Pillen et al., 2013; Schepens, et al., 2009).

Pillen et al. (2003) offer two arguments that attest to the utility of the construct of teachers' professional identity. On the one hand, it can be used by teachers as a resource that provides meaning, and on the other, it can function as an analytical lens for teacher learning and development. Additionally, Beijaard et al. (2004) state that teachers with a positive self-perception of their identity generate mechanisms that may even eliminate discontent in the face of precarious work conditions.

Some authors hold that the notion of teachers' professional identity is closely related to self-image, which is not separate from the life story or narrative of the individual (Kerby, 1991). In this sense, some studies emphasize the relationship of teachers' professional identity to concepts such as reflection or self-assessment (Cooper \& Olson, 1996). It has been posited that it is not possible to speak about oneself without reflection, so to develop a self-image as a teacher is it necessary to develop auto-reflective tools (Antonek et al., 1997). Nonetheless, it is important to consider that the construction of teachers' professional identity begins with their initial education and extends throughout their full professional career, with the potential to be continually reconstructed in spaces of continuing education.

\subsection{Science teacher identity}

Science teacher identity is an area closely linked to this study since the camp sought to reinforce the identity of science teachers using the ontological coaching approach. Regarding science teacher identity, Avraamidou (2014) carried out a metastudy to examine how its construction has been conceptualized and researched, synthesizing 29 empirical studies that give an account of the utilization of this concept. Science 
teacher identity offers a powerful and multidimensional lens to study teacher learning and development. It highlights the role of context for the teacher, casts light on teachers' personal stories in relation to science, and permits the examination of the impact of personal characteristics on teachers' learning and development (such as age, gender, emotions, and ethnicity).

A literature review centered on science teacher identity reveals characteristics that can build greater understanding of the particularities of teacher identity as a whole. Some research addresses the disciplinary characteristics of science and science teaching (Badia \& Iglesias, 2019; Avraamidou, 2016), while other studies consider community aspects. In this sense, Badia and Iglesias (2019) highlight that teacher identity is composed of experiences with science when teachers were in school and their adoption of the concept of effective science teaching. Likewise, Avraamidou (2016) describes three types of teacher identities, including those centered on the conception of what it means to be a teacher, feelings regarding the scientific discipline, and specific ways of teaching science. Meanwhile, Kier and Lee (2017) propose two key characteristics in science teacher identity: the conception of teaching and learning and the conception of the nature of science that teachers possess.

However, not all of the characteristics identified by these studies reveal the social aspect of science teacher identity, as posed in Avraamidou (2016), Beijaard, Meijer, and Verloops (2004), and Rushton et al. (2020). For Avraamidou (2016), teacher identity consists of interaction between educational biographies and institutional discourses. Meanwhile, Beijaard, Meijer, and Verloops (2004) indicate characteristics that involve the individual with their context, in which teacher identity consists of subidentities and agency is critical; this points to the necessity of teachers being active in the process of professional development. Rushton et al. (2020) emphasize the importance of shared identity and group membership as catalysts for the development of positive teacher identities, suggesting that being part of a group and socially constructing identities are crucial factors for strengthening teacher identity in general. In this context, teacher identities appear to be reinforced in communities in which their stories are heard in an active and critical manner in order to empower them as agents of change. Correspondingly, the camp experience examined in this study will be understood as a space in which teachers resignified their identities through reflective spaces, strengthening those aspects related to the meaning of teacher identity through shared experiences. 


\subsection{The "Explora Va!" Science Camp for Teachers}

Motivated by teachers' interest in participating in educational experiences similar to the summer science camps for youth held in countries such as the USA, Canada, and Finland, the Explora Program of Chile's Ministry of Science, Technology, Knowledge, and Innovation has implemented "Explora Va!" Science Camps for Teachers since 2017. These camps are utilized by teachers as a strategy to partake in continuing education in the transversal teaching of science that is in tune with the guidelines of the Ministry of Education. Teachers and administrators from all K-12 levels apply to these camps.

This study stems from the camp held in January 2018 in the town of Llifén, located in the Region of Los Ríos in southern Chile and surrounded by an environment of native forests, rivers, and lakes characteristic of the zone. The camp was implemented over the course of five days with a residential arrangement (i.e., "sleepaway camp"). One-hundred-and-four teachers, administrators, and educational assistants from around the country participated, coming from distinct disciplines and establishments both public and private, rural and urban, and with varying levels of social vulnerability.

The objective of the camp was to strengthen teachers' competencies as agents of change in their schools through the presentation and development of tools that allow value to be added to the educational community based on different dimensions of science and technology. The Explora Program understands the teacher as an agent of change with the capacity to design, manage, and implement activities inside and outside the classroom in order for students to develop thinking skills and individual attitudes in the sphere of science and technology: critical and reflective thinking, the development of curiosity, the ability to plan, and rigor and honesty in the collection of data and evidence.

During the camp, as secondary objectives, the teachers reflected on their own abilities and attitudes in the area of science and technology, the meaning of their teaching, and their links to other disciplines, as well as identifying the main nodes that hinder the development and appropriation of the skills and attitudes inherent in science and technology on the part of students. They also visualized alternative methodologies for science teaching based on reflection on their practice in collaboration with other teachers and school professionals, and generated learning 
communities for the collaborative construction of knowledge about educational improvement.

From the methodological point of view, the camp was designed using ontological coaching (Medina et al., 2019; Ortega, 2012) and the concepts of the reflective practical identity model (Galaz, 2011; Schön, 1983). In the case of the former, it is effective in the sphere of teacher professional development "because it contributes to the elevation of the consciousness of the teacher in diverse dimensions (including emotional and motivational) that condition ways of acting in educational contexts" (Medina et al., 2019, p. 21). Therefore, it leads participant teachers to recognize and seek out solutions to problems (Ortega, 2012), stressing their conceptions and knowledges in the areas of teaching, science, and their own pedagogical practices.

The reflective practical identity model is present in the leadership of teachers in the training program, who interact with their peers through dialog, daily coexistence, collaboration in activities, and moments of personal introspection. The activities promote processes of reflection and introspection on teachers' own identity constructions. The teachers recognize personal elements of what is learned socially on the nature and epistemology of science, which influences their agency as educational practitioners, and they resignify and reaffirm different components of their professional identity.

Based on both of these theoretical contributions, this instance proved to be meaningful for the teachers because they were able to reflect on themselves, their professional activities, and their educational environments and contexts. These spaces strengthened their competencies in terms of scientific research and the teaching of it, as well as those abilities linked to attitudes and values, including active listening, teamwork, and assertive communication. In all of the activities at the camp, including the journal-writing, there were moments aimed at generating a "bridge" between what was learned and experienced at the camp and teachers' agency in their own educational communities.

The contents of the camp included, in a progressive manner, the characteristics of scientific knowledge and their pedagogical transposition; the principles of science education based on inquiry; the links and overlaps between the sciences and other curricular subjects; reading comprehension; the error as a source of learning; stereotypes and learning in the sciences; appropriation and curricular development; the importance of questions in the development of scientific inquiry; the organization of learning environments; and lastly, the creation and monitoring of communities. 


\section{Activities were coordinated through a set of modules that provided for the integration of the Participatory Action Research methodology together with ontological coaching. In total, 11 pedagogical and ontological activities were included, complemented by recreational activities (see Table 1).}

Table 1. Activity programs implemented at the camp, in chronological order.

\begin{tabular}{|c|c|c|}
\hline Title & Dimension & Description \\
\hline $\begin{array}{l}\text { 1. I am part of } \\
\text { a "rope team" }\end{array}$ & Ontological & $\begin{array}{l}\text { The "rope team" (referring to the concept from climbing/mountaineering) as a metaphor } \\
\text { allowed for the strengthening of personal and professional development collaboratively and } \\
\text { synergistically, enhancing camaraderie, unity, cohesion, and teamwork, and utilizing them as a } \\
\text { learning process. Established at the start of activities, each member of the "rope team" of } 15 \\
\text { teachers, diverse in gender and teaching level, together with a facilitating teacher, made and } \\
\text { shared a postcard with their expectations and wishes when arriving at the camp. }\end{array}$ \\
\hline $\begin{array}{l}\text { 2. Pedagogical } \\
\text { paths }\end{array}$ & Pedagogical & $\begin{array}{l}\text { These were used to carry out a collective diagnostic on teachers' pedagogical practices. On a } \\
\text { path with three "stations" passing along a scenic natural route (lake, forest, mountain), each } \\
\text { teacher reflected on their teaching career, mediated by lead questions: What has my } \\
\text { relationship been with nature and how do I feel today in connection with nature; what has the } \\
\text { nature of my work as a teacher been; what experiences have distinguished my career } \\
\text { trajectory; how do I feel today in relation to the profession? A pedagogical assessor, as } \\
\text { facilitator, offered context to each of these questions, making a connection between the path } \\
\text { through nature and its changes, and the changes and experiences in their career paths in } \\
\text { terms of identity and teaching practices. Teachers shared their reflections in small groups, and } \\
\text { the facilitator summarized them in a plenary session afterwards. }\end{array}$ \\
\hline
\end{tabular}

3. The day's Ontological At the end of each day, the teachers did their journaling, a reflective activity oriented toward harvest and ontological coaching, which consisted of recording their daily reflections on a form with openjournal writing ended questions, "harvesting" the essential elements gathered during the day in the context of activities, science teaching, and learning at the camp. The last day, the question focused on the process of personal self-assessment in terms of the full experience of the camp. These narratives were utilized to identify and analyze aspects related to teacher identity in this continuing education experience.

$\begin{aligned} & \text { 4. Delving into Pedagogical } \\ & \text { our }\end{aligned}$
$\begin{aligned} & \text { On the second day, through small group conversations, group inquiry was carried out into } \\ & \text { pedagogical practices and conceptions, considering the nature of pedagogical knowledge in } \\ & \text { practices }\end{aligned}$
$\begin{aligned} & \text { the sciences. The teachers were shown the elements of a learning community in order to gain } \\ & \text { a collaborative vision of their work across different levels. The questions for this exercise } \\ & \text { included the following: What factors explain collaborative work, and what advantages and } \\ & \text { disadvantages does it have; what causes and consequences can impinge on collaboration; } \\ & \text { what elements of the camp experience mirror the experience of the classroom, and how? The } \\ & \text { group conclusions were shared in a plenary session. }\end{aligned}$

5. Identifying Pedagogical The objective here was for teachers to identify the critical nodes that impact their pedagogical pedagogical work, considering the change of paradigm in science teaching from instructional to nodes constructivist. After carrying out a recreational activity of moderate difficulty (kayaking, trekking, climbing), they discussed as a full group the negative and positive emotional states experienced, and how these reflected daily pedagogical practices. Group discussions addressed the value of nature as a classroom, its potential as a complement to the traditional classroom, and the challenges that its utilization entails. Then, the teachers looked for solutions to these problems and challenges, using the elements of the previous recreational activity, that is, collaborative and reflective work and the relevance of personal pedagogical knowledge as a source of improvement for science teaching. The results were shared in a plenary session. 


\begin{tabular}{|c|c|c|}
\hline $\begin{array}{l}\text { 6. Project } \\
\text { creation }\end{array}$ & Pedagogical & $\begin{array}{l}\text { Each "rope team" designed two plans of action to implement as solutions to the critical nodes } \\
\text { identified in the previous activity. Each project contained the elements identified in the } \\
\text { construction of learning experiences that promote inquiry in any scientific discipline, using the } \\
\text { individual and collective pedagogical knowledge of the participants as a theoretical } \\
\text { framework. The activity was divided into four stages (one per day). During brainstorming } \\
\text { (stage 1), they agreed on two plans of action to work with. In project formulation (stage 2), } \\
\text { they developed the theoretical framework, hypothesis and objectives, methodological design, } \\
\text { expected results, and projections. During poster creation (stage 3), they synthesized the main } \\
\text { elements of the project for their exhibition, feedback, and exchange at the "Teachers' } \\
\text { Convention" (stage 4). }\end{array}$ \\
\hline
\end{tabular}

7. Inquiry and Pedagogical
experimentati
on in the
natural

sciences

Visiting the region's coastal area, the teachers carried out an inquiry activity on the identification of marine fauna in the intertidal zone based on the Inquiry Cycle (Feinsinger, 2014). Utilizing this natural laboratory, and based on guided questions on zone formation and diversity, they carried out observation, information gathering, data analysis, discussion, synthesis, reflection, and generation of new questions. With their collected information and the instrumental information available, the teachers were challenged to construct an inquiry activity for their students incorporating the principles of the Inquiry Cycle and those of a learning community (i.e., construction of collective, conversational, reflective knowledge, centered on the error as a source of learning) with a focus on the process of participatory action research by students. The question was constructed based on the identification and classification of samples with the parameters they defined considering the level of their students. The results were presented in a plenary session using scientific posters.

8. Inquiry and Pedagogical Similar to the previous dynamic, this activity involved the construction of social scientific experimentati knowledge in an on-site museum, where the teachers had to observe and characterize the on in the visitors, recording patterns of dress, age, gender, and behavior associated with specific social sciences sections and most-visited attractions in the museum. This characterization permitted the exploration of a social laboratory as a source of scientific inquiry to be extrapolated to nearer social contexts (to the teachers) such as the school yard, the classroom, the neighborhood, or the community.

9. Agents of Ontological
change and
the creation of
learning
communities

The objective was for the teachers to adopt significant changes in terms of their vocation and their empowerment as agents of change in their educational communities. To establish this dynamic, the world café was utilized, a methodology that creates networks of collaborative dialog utilizing powerful conversational processes. Complex questions were explored, connecting the different conversations in order to generate new discoveries. The findings, learning, and opportunities for action were systematized and shared in a final plenary session.

10. Dialogs with leading ambassadors in education
Ontological This was an instance of conversation moderated between a teacher/principal of an educational establishment promoting notable STEAM initiatives, and small groups of teachers. The ambassadors related their experiences in educational improvement, achievements, difficulties, and solutions. They reflected on their skills and attitudes toward the sciences, the meaning of their teaching, and their links with other disciplines. Additionally, a dialog with students was carried out with noteworthy participants in STEAM activities and/or students who had experienced significant motivation in the area thanks to their teachers. They related their school experiences and how this influenced the quality of their learning and their valuation of science and technology.

11.
Community

This ceremony encouraged the participation of each attendee in order to recall the experiences of the camp, considering the networks built, the reflections developed regarding their teaching practices, and the changes in attitude that arose within them. The ceremony contained symbolic elements that appealed to the emotions and community spirit, with a recap of everyone's experiences via audiovisual captures in an inspiring, reflective, and festive atmosphere. Participants' sense of belonging and loyalty was encouraged and strengthened. 


\subsection{Objectives and study design}

The objective of this study was to analyze the continuing education experience of the teachers participating in the Explora Va! Camp and the effects of this experience on teachers' professional identity, from the perspective of the teachers themselves.

The general methodology utilized for the gathering and analysis of information followed the protocols of a qualitative study from a comprehensive theoretical perspective. The journal analysis was carried out using directed qualitative content analysis centered on the contextual meaning of the text (Tesch, 1990). Hsieh \& Shannon (2005), analyzing three approaches to content analysis, recommend this method when key concepts have been identified that guide the coding of initial categories. In the case of this study, current theoretical developments regarding the construction of teacher identity served as an analytical lens for understanding teachers' reflections on the processes experienced at the camp.

The technique utilized for the collection of information was the daily recording of statements by each participant, which were written in a reflection journal designed using the Google Forms application. With the objective of evaluating the impact of daily programmed activities, participants answered questions in the "daily harvest" that invited reflection on the camp in a different manner each day. The daily reflection questions were related to the objectives of the day's activities, which were designed by the camp's pedagogical team (see Table 2).

The aim for was the teachers attending the camp, who formed the unit of analysis of this study, to carry out an open, evaluative reflection on the dimensions of the experience that affected them most. These narratives would later by analyzed. The discourses registered in the journals were examined through qualitative content analysis (Denzin \& Lincoln, 2005), and the answers to the questions were entered as text documents into the qualitative analysis software MaxQda (version 11 for Windows). Coding was initially carried out by seeking textual fragments that indicated reflections associated with teacher identity. In the second level of analysis, these textual fragments were placed in pre-determined categories of teacher identity, either personal or contextual. Once the texts were grouped into these two category types, the next step was to select and interpret those that indicated self-perceived changes that teachers believed were a result of the camp. 
Table 2. Reflection questions in the journals.

\begin{tabular}{|c|c|}
\hline Day & Activity/Reflection questions \\
\hline Journal day 1 & $\begin{array}{l}\text { Hello and welcome! Today was a day for us to get to know each other and talk about our } \\
\text { expectations. Write about your sensations, experiences, and impressions from today and } \\
\text { what you hope for during these five days of Camp. } \\
\text { We'll also reflect on who we are, and on our path as teachers. } \\
\text { What have you harvested from this pedagogical path? }\end{array}$ \\
\hline Journal day 2 & $\begin{array}{l}\text { Hello! Today we carried out challenging activities in the fresh air, reflecting on teamwork } \\
\text { and learning communities. How do you think that you could promote collaborative work } \\
\text { in your pedagogical role? What advantages and/or disadvantages do you see in } \\
\text { teamwork? What factors could impinge on collaboration? Tell us your reflections. } \\
\text { During the course of the afternoon we also talked about the difficulties that we } \\
\text { confronted as professionals (pedagogical nodes). What sticks with you from this } \\
\text { conversation? }\end{array}$ \\
\hline Journal day 3 & $\begin{array}{l}\text { Today we visited various places where we could sense and experience the construction } \\
\text { of scientific knowledge in distinct disciplines. What are your reflections on the visit and } \\
\text { inquiry carried out? Why do you think the research question is important, and in what } \\
\text { way do you think that today's experience could be useful to you in your pedagogical } \\
\text { practice? }\end{array}$ \\
\hline Journal day 4 & $\begin{array}{l}\text { Today we created an inquiry activity for our students as a group. What did you take from } \\
\text { this experience of collective construction? } \\
\text { We also had the opportunity to converse with educational leaders. What did you harvest } \\
\text { from this exchange with your colleagues? } \\
\text { We are one day away from the end of Camp. How have you felt during the past several } \\
\text { days? (Consider both the positive and negative aspects of this experience). }\end{array}$ \\
\hline Journal day 5 & $\begin{array}{l}\text { On this final day of camp, compare the agent of change that you were before and the } \\
\text { one you are today. Reflect on this. }\end{array}$ \\
\hline
\end{tabular}

It should be noted that in order to grant validity and reliability to this study, triangulation was carried out (Martínez, 2006). Thus, during the camp and research process, professionals participated from the areas of anthropology, sociology, the natural sciences, and education, offering different disciplinary viewpoints. These materialized through discussions and dialogs during in-person meetings as well as via digital communication. 


\section{Results}

\subsection{General findings}

The narratives in the journals give an account of the heterogeneity of teachers' experiences at the camp and relate to the dimensions of their professional identity.

The most abundant categories represent aspects that are mostly confined to the personal dimension of teachers' professional identity. Among these, reflections that describe self-perception stand out, as teachers valued positive personality traits that were not fully recognized before. Narratives of change in their self-definition as teachers also emerge, as well as a resignification of their role in the educational community.

In terms of the categories of the contextual dimension, those related to professional performance and the difficulties of working in adverse political/institutional settings emerge. This class of category appears in much lesser magnitude than those of the personal dimension. Figure 1 illustrates the main emerging categories associated with the journal texts.

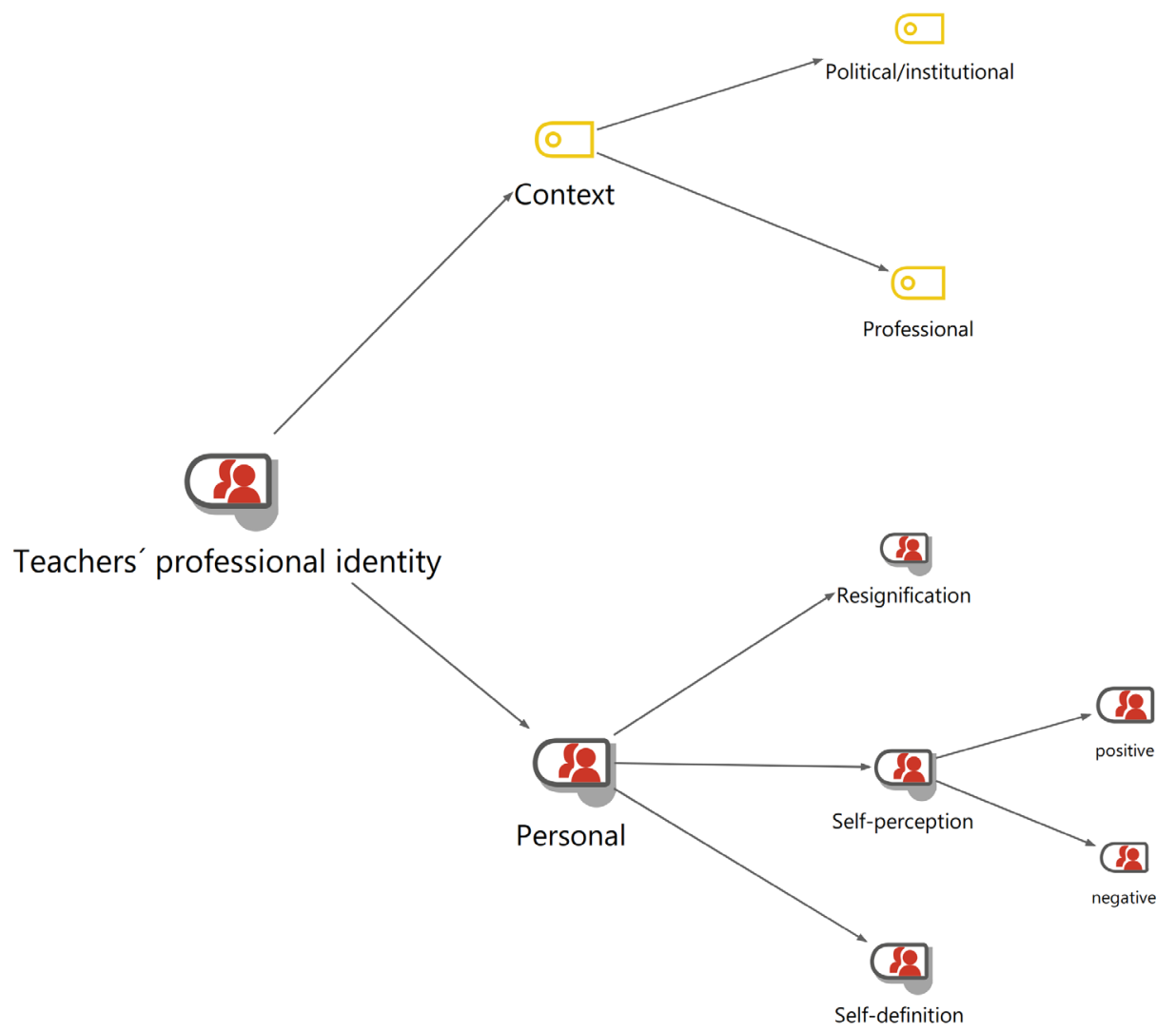

Figure 1. Main categories associated with the journal texts, related to dimensions of teachers' professional identity. 


\subsection{Personal dimension}

In their narratives, the teachers mention expectations that are strongly linked to the emotions and feelings that emerge before an unfamiliar situation. Thus, in their first entries they speak of anxiety alongside the desire to enrich their professional and pedagogical practices through exchanges with their peers and the tools provided in the activities.

However, gradually they begin to indicate that the natural and social environment developed at the camp has offered them a distinct personal and professional learning opportunity centered on themselves. Thus, they signify it as a unique time and space to rethink both satisfying and challenging experiences. In this sense, they emphasize common elements in the definitions of their identities, mainly associated with professional and affective factors that they share, such as passion for their work and love for their students, along with recognizing shared hopes and issues.

In this regard, some teachers express that they have experienced changes in terms of their behavior in the presence of others. They self-define as more sociable, which is expressed in the desire to get to know others, have fun, and feel comfortable with their peers. This attitude invites them to innovate as well as to confront failure or error in the presence of others.

"Before the Explora Va! Camp I felt like I had fewer social skills, less ability to advance on projects, was less decisive, with little capacity to innovate, to take the first step, with fear of errors or failure. After the Camp I see myself looking hugely forward to working, creating spaces to improve students' learning, with more strategies to motivate them" (A.S. Primary School Teacher)

Self-confidence is another category that emerges from the narratives. Somewhat related to the sensation of greater sociability mentioned previously, some teachers self-defined as having fewer apprehensions about relationships and interactions with others.

"Before arriving to the camp I had many fears, apprehensions, I didn't want them to ask me about some specific issue because of fear of talking, I didn't know how I was going to relate with the other people and much less what was coming. However, from the first day that I arrived, those fears left me" (P.A. Primary School Teacher)

A resignification of cognitive capacities also seems to have occurred. Some teachers describe leaving the camp with more skills and capacities for learning and 
knowing. These changes are expressed in the narratives as feeling more intelligent, understanding things, and feeling more intellectually capable.

"The agent of change that leaves this Camp is one who carries a backpack full of new experiences and a great enthusiasm for innovating in my pedagogical work. I think that the one who arrived was a person with expectations to learn only knowledge perhaps, but the one who leaves today is a person that knows that the most important thing is developing abilities to be able to understand that knowledge and capture it in a good way for my students" (R.I. Primary School Teacher)

Some teachers highlight the resignification of their teaching role during the camp experience following a loss of motivation in their professional work influenced by colleagues at their school. The experience of the camp is underscored as an openingup and change of internal locus from worrying about problems to worrying about solutions.

As a teacher, I only have three years of work experience, so arriving at my first job, which is where I still am today, I came with my backpack full of ideas and projects to do. Thankfully, I found myself with an administrative team that supported each of my ideas, so we were able to do many new things. However, as time passed, I began to notice the malaise of my colleagues, which greatly discouraged me, causing me to limit my creativity and desire to generate changes in the establishment. During this camp, I've regained my desire to contribute to change, empowering myself based on my abilities and changing focus, because I can't limit the well-being of my students for the comfort of my colleagues" (Pre-school Educator)

In addition, they resignify their work based on the use of their surroundings as a space of learning in the sciences and as an alternative to the classroom. Referring to specific activities from the camp, they describe feeling like students again and experiencing newfound curiosity. The notion of "meaningful learning" repeatedly appears as a justification for this type of educational experience. They also value being introduced to inquiry-based learning and its transversality in distinct subjects, but they identify it mainly as a resource applicable in natural environments and to a lesser degree in their social environments. One example of this distinction came about when certain teachers recognized the difficulties that they had experienced in observing and forming questions in the case of social inquiry. In general, they internalized the importance of the question within the systematic process that the inquiry method addresses, justifying its relevance as a guiding element for learning amongst their students as well as in the process of scientific research. 
It follows that some narratives give an account of reflective processes that place value on practical knowledge not centered exclusively on curricular knowledge; the latter often generated fears of exposing educational weaknesses among the other teachers.

\begin{abstract}
"From that point I was no longer afraid of giving my opinion, presenting my lived experiences, giving my ideas to execute some project, or I even thought of the possibility of stopping on the stage to share one of our big projects. I feel that I'm leaving as an agent of change with the desire to implement a new type of education for my students and also share my experiences with my colleagues and motivate them to participate in the next Camps so we can all be agents of change and we can connect and establish a community with innovative agents" (P.A. Primary School Teacher)
\end{abstract}

Meanwhile, some teachers exhibit a greater acceptance of the uncertainty and risk involved when desiring to innovate in pedagogical practice. They also indicate that the experience helped them as a new motivational boost to continue on the same path, but now with a wider range of possibilities in their work.

Other aspects that emerge from the narratives center around a very positive evaluation of the camp, of the organization's personnel and the design of the activities. One aspect that stands out is the frequent mention of the experience as a space of emotional support, which could point to the scant concern for mental health encountered by teachers today in the exercise of their profession. This corresponds to the links forged in the social dimension of professional identity, specifically in terms of the recognition of teachers' work, which they consistently find to be less than deserved. Participants also recognize the prevailing educational accountability systems in Chilean education, in which standardization and measurements play an overbearing role.

\title{
4.3 Contextual dimension
}

Although present to a lesser degree, the narratives that point to changes in the contextual dimension of teachers' professional identity illustrate a sensation of greater professional competence and greater ability to achieve meaningful learning with their students. This latter point, for many teachers, constitutes the ultimate objective of their professional identity and duty throughout their career paths. It provides motivation that helps them withstand the various difficulties that arise at personal, institutional, political, or cultural levels. 
Amongst these contextual factors, the teachers' entries emphasize the scant recognition of their role and the conditions in which they carry out their teaching. Both situations are linked to the characterizations of their work that they believe to be present in Chilean society, as well as to the discrepancies between what they desire and what they experience on a daily basis in their schools.

"Oftentimes we feel insignificant in this big world, and as teachers: an undervalued job. However, today I felt proud to be one. Listening to my other colleagues talk about their work and their labor with so much love and devotion, made me feel truly important as a teacher... Today my harvest is that, feeling proud to be a teacher.” (P.H. Secondary School Teacher)

Some professors describe feeling more productive and creative, and their discourses reveal a greater valuation of collaborative work. In this sense, they express that the camp helped them realize that they feel alone in their profession at times. However, this new experience and the work with their peers through dialog and reflection allowed them to visualize problems shared in common and feel like part of a professional community. Indeed, in some cases, a heightened opinion of collaborative work is communicated, and there seems to be a change of attitude toward innovation in educational work based on viewing knowledge as a process of inquiry more than a transmission of information. It follows that certain attitudes toward teaching through cooperative strategies also shifted.

"I timidly began to assume certain roles that generated some different and positive dynamic in my establishment, but now I have realized all the dimensions in which one can develop that attitude of change. The camp opened my mind to take on that challenge. The experience has given me the capacity to analyze my work and activate my creativity to incorporate the meaning of collaborative and personal work within my practice, as well as to realize that being an agent of change is much more than a mere activity, it is a professional lifestyle. Before I simply thought that one different activity was enough, but today by contrast I know that this is not so, rather, I must have a sustained, patient, responsible, and challenging attitude, day-to-day, in my future pedagogical work" (T.D. Secondary School Teacher)

\section{Discussion}

The journal narratives provide an account of key moments and insights experienced during five intense days of camp. The teachers make explicit, among other things, the definitions that each one has of themselves as professionals, the place that they occupy in their work context, and their motivations regarding the work of educating. 
In this sense, the experience of the camp acted as a mechanism that facilitated collective reflection with the goal of learning from the experience and from the others present, in order to generate knowledge from and for the practice of teaching (Schon, 1998). This type of experience could have a strong effect on positive self-perception, and therefore on changes in conduct in which self-perceptions organize experiences and guide behaviors (Swann et al., 2007).

The participation of teachers in the camp allowed them to question their personal impressions, beliefs, and expectations about traditional forms of capacitation and improvement that they had experienced on other occasions. These experiences have been described previously as institutional actions guided by experts that deliver disciplinary contents, procedures, or pedagogical methods that aspire toward improved professional performance, aimed at resolving the shortcomings or deficits in teachers' work (Vezub, 2013). Differences have been reported in this context between the theoretical aspects of teacher education and their pedagogical practice in situ at schools, claiming that the former are removed from the necessities and interests of educators in the daily realities of their work and professional roles (Qablan et al., 2015; Busquets et al., 2016; Marcelo \& Vaillant, 2013; Vaillant, 2019). Theory often points to a rationalist, technocratic, and utilitarian vision steered toward individual performance, based on quantifiable elements of effectiveness-efficiency with pre-established models or navigation charts approved for achieving expected learning outcomes in students. However, such approaches do not consider the voice of the educators-their cognitive, emotional, and valuation processes (Brito, 2018; Casassus, 2006; Ferrada, 2017; Vezub, 2013).

This conservative approach to education is not absent from the area of the sciences. Several teachers participating in the camp declared an initial expectation of gaining tools that would simply enable them to teach the sciences (mainly natural). Although based in an epistemology of moderate rationalism, they ultimately voiced the need and interest to obtain knowledge and teaching strategies to promote more meaningful learning in their studnts. This is important in terms of how they address the world stage and contemporary global issues, which due to their complexity must be analyzed and resolved from different perspectives based in the natural sciences as well as the social sciences (Busquets et al., 2016; González-Weil et al., 2014; Fernández et al., 2002; Quintanilla et al., 2020; Triviño, 2018).

Fernández et al. (2002) argue that these ways of thinking about scientific activity are based on epistemologies that have produced distorted visions of science teaching 
at different educational levels. Such visions tend to hold science as a solitary, individual activity centered on observation; experimentation without hypotheses or guiding theories; rigid and timeless work sequences disconnected from the social issues of the moment; and an analytical and cumulative version of knowledge.

Likewise, these conceptions related to the radical rationalist or positivist view (Quintanilla et al., 2020) define teacher education based on a version of science teaching that purports to disseminate scientific knowledge to students in an abstract, standardized, and homogeneous manner that is detached from the present times. This vision, reflected in the writing of some teachers participating in the camp, could be linked to their own school trajectories, their undergraduate education, and other instances of continuing education in which they have participated, which together have instilled a certain way of conceiving of and teaching science (González-Weil, et al., 2014; Quintanilla et al., 2014).

Based on a moderate rationalist epistemology, many participants demonstrated interest in and need for increased knowledge and teaching strategies to promote more meaningful learning for their students in terms of how they can confront the world stage, which today includes environmental problems, food shortages, mass migration, pandemics, large-scale violence, and discrimination, among other issues. Due to their complexity, such issues must be analyzed and resolved from different perspectives, based on both the natural and social sciences (Busquets et al., 2016; González-Weil, et al., 2014; Fernández, et al., 2002; Quintanilla, et al., 2020; Triviño, 2018).

Accordingly, discrepancies can be observed in the camp participants in terms of differing perceptions, conceptualizations, objectives in science teaching, and teachers' genuine interest in helping their students achieve scientific capabilities and skills, which may be linked to the personal experiences of each educator with science, and which in their professional work moves between positivist and moderate rationalism (Quintanilla et al., 2020). Lapasta (2018) states that it is necessary to understand professional learning from a constructivist viewpoint, incorporating learners' previous, current, and future experiences: “...if epistemological and psychopedagogical reflection is not promoted at the same time in relation to the area of disciplinary knowledge, it is unlikely that they will manage to make a change in terms of the practice of science teaching" (p. 113). These elements are important for achieving innovations on the current world stage, where science resonates energetically as a means to find certainties and answers. Likewise, to achieve changes in teachers' practices, instances of continuing education should incorporate specific, 
concrete activities where innovations and new theoretical advancements in the disciplines taught are undertaken in classroom contexts. This implies teachers experiencing, in a situated manner, the knowledge that has emerged from new research (Solbes et al., 2018). Camp activities involving natural and social inquiry allow the experience of constructing and teaching scientific knowledge based on visions of education removed from disciplinary limits and conventional teaching strategies aimed at simply reproducing knowledge. They are situated in scenarios that go beyond personal professional identity toward collective identities, related to collaborative learning and teaching of science in meaningful settings, which can be carried over to the classroom with the adaptations and contextualizations that teachers deem necessary.

In line with these arguments, González-Weil et al. (2014) state that educators should create a shared view on the meaning of science teaching, inquiring and reflecting personally and collectively on their practices and recognizing the value of the experience as knowledge that allows for learning in situated settings that are diverse and particular to each school, grade level, and classroom (Quintanilla, et al., 2020).

In this sense, our study demonstrates teachers' positive valuation of participating in the camp modality, an opportunity for continuing education to recall and reflect on personal and professional experiences and inquire further based on educators' narratives and personal stories (Pirrone, 2006). However, Alsup (2006) indicates that these narratives are influenced by both personal and external truths about the concept of being a good teacher, held by colleagues and the wider society, that exist in a process of negotiation in the construction and resignification of teacher identity between their agency and the environment, which is not always harmonious. The new experiences acquired at the camp could either link up or create tension with conceptualizations of the self and of the profession (Beauchamp \& Thomas, 2009; Beijaard et al., 2004; Schepens et al., 2009; Ruohotie-Lyhty, 2018). This, despite the fact that the Explora Va! Camp is fully in keeping with the current tenets and principles of continuing education in Chilean public policy (Ruffinelli, 2016), which aim for professionals to research, reflect, and collaborate amongst themselves and other school actors. Teachers' learning, therefore, takes place throughout their personal and professional journeys in both formal and informal activities (Vezub, 2013). The latter are carried out, according to Calvo (2014), "through professional encounters and conversations among peers; reading and inquiry on the diverse factors involved in the work of 
teaching; the detection of one's own educational needs; and reflective and informed decision-making and returning to decisions to refine and transform them" (p. 113).

In relation to this latter point, teachers underscore the processes of individual and collective reflection that occurred throughout the diverse activities carried out at the camp, rating them as a unique opportunity, a new territory, and a time to contemplate about themselves, their peers, and the different school environments that they have inhabited and co-inhabited during their professional journeys. This produces interesting results since the literature has uncovered little in the way of spaces for critical reflection in initial or continuing education (González-Weil, et al., 2014; Quintanilla, et al., 2020; Vezub, 2013). This represents a barrier to teacher selfdefinition and to their relationship with their students, considering that their agency and authority could be confronted in the classroom in situations in which their personal and professional identity must be demonstrated when they have not reflected on it previously (Alsup, 2018; Fraser et al., 2007).

In the area of the sciences, the limited space available for reflection and communication also has a great impact, considering that teaching in schools should aim for students to become conscious of their intervention and participation in society based on "(...) making informed decisions, and establishing robust value judgements by activating, in an autonomous and critical manner, those cognitive-linguistic competencies that give coherence to their thinking, their discourse, and their actions regarding the natural world" (Quintanilla et al., 2014, p. 17). Toward this end, the development of critical thinking skills, metacognition, and capacities associated with empathy, solidarity, camaraderie, and curiosity should also be a concern for teachers throughout their professional journeys. Utilizing a reflective perspective in teaching education activities permits going beyond pedagogical aspects to incorporate the interior world of each teacher; their thoughts, principles, emotions, explanations of their undertakings, and their own construction of their professional being (Vanegas \& Fuantealba, 2019). Participants valued the camp spaces that allowed for personalprofessional dialog and conversation with their colleagues. These served to reaffirm and reconstruct their professional identity based on both divergent and convergent viewpoints of being, doing, and knowing the role of the teacher (Ruohotie-Lyhty, 2018). This occurred both in the sphere of the sciences and in those areas that they identify as strengths, weaknesses, and common needs as educators, independent of the subjects they teach. In fact, common discourses emerged in the camp's reflection activities, despite the diversity of specializations, professional stages, age ranges, 
geographical locations, and realities of the participants, revealing that the work of educating is linked to a tradition of teaching as a profession already received in its scope of action and domain of performance (De Tezanos, 2012), drawing from common knowledges learned during preparation and teaching practices (Tardif, 2010; Beijaard et al., 2004). This structure can enhance collective identity, but it could also impinge on innovation and the changes demanded by society, generating resistances if teachers perceive that public policy is implementing transformations that do not align with the reality of the school (Hargreaves, 2003; Marcelo \& Vaillant, 2013).

To achieve effective transformations, as evinced by the analysis of the journals, educators must first reflect on their own professional identity and the different changes that they will go through across the span of their career path (Day, 2011). This “...allows thinking about the transformation of teachers' practices, since it opens the spectrum of relationships among subjects, knowledges, and cultures involved therein" (Vanegas \& Fuantealba, 2019, p. 120).

Likewise, Vaillant (2019) and Calvo (2014) emphasize that the teaching profession should stop being understood as a solitary labor, given that current challenges and daily school dynamics allow lifelong learning by teachers based on their experiences, reflections, decisions, and shared actions with their colleagues. Teaching itself is a supportive profession that incorporates individual but also collective knowledges learned along the way, and the central idea of collaborative professional learning is recognizing that teachers learn from their pedagogical practices (Calvo, 2014) and that this occurs based on their interactions with colleagues in various shared instances, both planned and spontaneous.

For the teachers, the camp represented an accommodating space, as they positively valued the coordination of pedagogical and recreational activities, the organizational routine, and the open-air spaces as scenes for connection with their biographical and professional stories and those of their colleagues, as well as with nature itself, above all feeling recognized in their professional role. This finding is important given the loss of prestige and recognition of teaching in Latin America resulting from distrust of institutions, weaknesses in initial and continuing education, the increasing precariousness of teaching as a profession (Elacqua et al., 2018; Marcelo \& Vaillant, 2013; Vaillant, 2019), and the discrepancy between the demands of the profession and the social, economic, political, and cultural transformations that have taken place during the past few decades (Ferrada, 2017; Hargreaves, 2003; 
Marcelo \& Vaillant, 2013; Vezub, 2013). In this sense, the camp contributes to the development of educators' socio-affective competencies, mainly regarding professional self-esteem-understanding their relationships with satisfaction, identity construction, and the performance and evaluation carried out by other actors in the school in terms of the work of teaching (Peñaherrera et al., 2014).

\section{Final reflections}

Based on the narratives of teachers from the camp, we can establish that any instance of continuing education should not only be linked to pedagogical knowledge and competencies, but also seek to incorporate information about professional selfrecognition and self-worth as important elements of pedagogical labor, which requires commitment, motivation, and a positive perspective on the role that each educator performs in the classroom (Peñaherrera et al., 2014). In this sense, continuing education in the camp modality aspires to highlight the importance of the teaching profession and of science teaching beyond the traditional canons and disciplinary limits conventionally envisioned. Based on shared issues encountered throughout the participants' careers, collaboration, innovation, and change in and with others signifies and resignifies professional identities beginning with common elements, but attending to the particulars and unique stories of each person. Following the camp, the new challenge that arises is the creation of professional networks that endure in time and position participants in their respective educational communities as a cohort of professionals with a vision and scientific tools to support their colleagues in the continuous search for solutions to the quotidian problems that are experienced in schools and society in general. The "Explora Va!" Science Camp for Teachers envisages teacher education as a model that operates in an active manner, generating spaces that permit reflection and increasing teachers' agency and critical thinking about their pedagogical practice.

In this sense, it is interesting to highlight that the experiences of both the camp and of this study took place within the context of Latin America and specifically that of Chile. For this reason, these projects attempt to contribute to the development of situated knowledge both drawn from and meant for communities of teachers. In addition, they seek to identify important elements of the teaching profession based on the voices of its practitioners, which can help public policy designers, researchers, and all those who find themselves working in the area to take the actions most relevant to the reality of schools and teachers. 
Lastly, new questions also arise for future research in this area, including, among others: What is the long-term impact of teachers' camps on the process of teacher identity formation? How do the professional capacities developed strengthen the pedagogical practices of teachers in their educational communities? What is the impact of teachers' camps on their epistemological beliefs regarding science and its teaching?

\section{Acknowledgements}

The camp and this study were funded in part by resources from the projects ECPI170007 and ER190005 of CONICYT Chile.

\section{References}

Aflalo, E. (2014). Advancing the perceptions of the nature of science (NOS): Integrating teaching the NOS in a science content course. Research in Science \& Technological Education, 32(3), 298-317.

Alsup, J. (2006). The Struggle of Subjectivities: Narratives of Tension. In J. Alsup, Teacher identity discourses. Negotiating personal and professional spaces (pp. 51-76). Lawrence Erlbaum Associates.

Alsup, J. (2018). Teacher identity discourse as identity growth: stories of authority and vulnerability. In P. Schutz, J. Hong, \& D. Cross, Research on teacher identity: Mapping challenges and innovations. Springer.

Antink-Meyer, A., Bartos, S., Lederman, J.S., Lederman, N.G. (2016). Using science camps to develop understandings about scientific inquiry-Taiwanese students in a us summer science camp. International Journal of Science and Mathematics Education, 14 (1), 29-53.

Antonek, J. L., McCormick, D. E., \& Donato, R. (1997). The student teacher portfolio as autobiography: Developing a professional identity. The Modern Language Journal, 81(1), $15^{-27 .}$

Avraamidou, L. (2016). Intersections of life histories and science identities the stories of three preservice elementary teachers. International Journal of Science Education, 38(5), 861884.

Backhus, D.A. \& Thompson, K.W. (2006) Addressing the nature of science in preservice science teacher preparation programs: Science educator perceptions. Journal of Science Teacher Education, 17, 65-81.

Badia, A., \& Iglesias, S. (2019). The Science teacher identity and the use of technology in the classroom. Journal of Science Education and Technology, 28(5), 532-541.

Barab, S. A. \& Hay, K. E. (2001). Doing science at the elbows of experts: Issues related to the science apprenticeship camp. Journal of research in science teaching, 38(1), 70-102.

Beauchamp, C. \& Thomas, L. (2009). Understanding teacher identity: An overview of issues in the literature and implications for teacher education. Cambridge journal of education, 39(2), 175-189.

Beijaard, D., Meijer, P. C. \& Verloop, N. (2004). Reconsidering research on teachers' professional identity. Teaching and teacher education, 20(2), 107-128. 
Brito, J. (2018). Formación y evaluación docente bajo el alero del neoliberalismo: el caso chileno. Revista Saberes Educativos, (1), 102-116

https://sabereseducativos.uchile.cl/index.php/RSED/article/view/51609/53977

Busquets, T., Silva, M. \& Larrosa, P. (2016). Reflexiones sobre el aprendizaje de las ciencias naturales: Nuevas aproximaciones y desafíos. Estudios pedagógicos, 42(ESPECIAL), 117135 .

Calvo, G. (2014). Desarrollo profesional docente: El aprendizaje profesional colaborativo. En UNESCO-OREALC, Temas críticos para formular políticas docentes en América Latina y el Caribe: El debate actual (pp.112-156)

http://cedle.cl/wpcontent/uploads/2016/o9/UNESCOTemasCriticosparaFormularNuevas Politicasdocentes.pdf

Casassus, J. (2006). La educación del ser emocional. Editorial Cuarto propio.

Cooper, K., \& Olson, M. R. (1996). The multiple 'I's' of teacher identity. In M. Kompf, R. Bond, D. Dworet \& T. Boak (Eds.), Changing research and practice: Teachers' professionalism, identities and knowledge (pp.78-89). The Falmer Press.

Day, C. (2011). Pasión por enseñar. Narcea.

Denzin, N. \& Lincoln, Y. (2005). The Sage handbook of qualitative research. (3 ${ }^{\mathrm{a}}$ ed.). Sage.

Elacqua., G., Hincapié, D., Vegas, E., Alfonso, M. \& Paredes, V. M. (2018). Profesión: Profesor en América Latina ¿Por qué se perdió el prestigio. Banco Interamericano de Desarrollo.

Feinsinger P (2014) El Ciclo de Indagación: una metodología para la investigación ecológica aplicada y básica en los sitios de estudios socio-ecológicos a largo plazo, y más allá. Bosque 35(3), 449-457.

Ferrada, D. (2017). Identidad docente frente la calidad como estandarización en las escuelas de la región del Biobío. Revista Latinoamericana de Educación Inclusiva, 11(1), 93-107. http://dx.doi.org/10.4067/So718-73782017000100007

Fernández, I., Gil, D., Carrascosa, J., Cachapuz, A. \& Praia, J. (2002). Visiones deformadas de la ciencia transmitidas por la enseñanza. Enseñanza de las Ciencias, 2O(3), 477-488.

Fields, D.A. (2009). What do students gain from a week at science camp? Youth perceptions and the design of an immersive, research-oriented astronomy camp. International Journal of Science Education, 31(2), 151-171.

Flores, M. A. \& Day, C. (2006). Contexts which shape and reshape new teachers' identities: A multi-perspective study. Teaching and teacher education, 22(2), 219-232.

Foster, J.S. \& Shiel-Rolle, N. (2011). Building scientific literacy through summer science camps: A strategy for design, implementation and assessment. Science education International, 22(2), 85-98.

Fraser, C., Kennedy, A., Reid, L. \& Mckinney, S. (2007). Teachers' continuing professional development: Contested concepts, understandings and models. Journal of in-service education, 33(2), 153-169.

Galaz, A. (2011). El profesor y su identidad profesional ¿facilitadores u obstáculos del cambio educativo? Estudios pedagógicos, 37(2), 89-107. https://dx.doi.org/10.4067/So71807052011000200005

González-Weil, C., Gómez, M., Ahumada, G., Bravo, P., Salinas, E., Avilés, Pérez J. L. y Santana, J. (2014). Principios de desarrollo profesional docente construidos por y para profesores de ciencia: una propuesta sustentable que emerge desde la indagación de las propias prácticas. Estudios Pedagógicos, 40(especial), 105-126. https://doi.org/10.4067/So71807052014000200007

Hargreaves, A. (2003). Enseñar en la sociedad del conocimiento. Octaedro 
Hong, J. Y. (2010). Pre-service and beginning teachers' professional identity and its relation to dropping out of the profession. Teaching and teacher Education, 26(8), 1530-1543.

Hsieh, H.-F., \& Shannon, S. E. (2005). Three Approaches to Qualitative Content Analysis. Qualitative Health Research, 15(9), 1277-1288. https://doi.org/10.1177/1049732305276687

Jacoby, M. (2013). Training camp for science teachers Hands-on materials science program helps educators engage students. Chemical \& Enginnering news.

Karaman, A. (2016) Professional Development of Elementary and Science Teachers in a Summer Science Camp: Changing Nature of Science Conceptions. Australian Journal of Teacher Education, 41(3), 158-192.

Kennedy, A. (2014). Understanding continuing professional development: the need for theory to impact on policy and practice. Professional development in education, 40(5), 688-697.

Kennedy, A. (2005). Models of continuing professional development: A framework for analysis. Journal of in-service education, 31(2), 235-250.

Kerby, A. P. (1991). Narrative and the self. Indiana University.

Kier, M. W., \& Lee, T. D. (2017). Exploring the role of identity in elementary preservice teachers who plan to specialize in science teaching. Teaching and Teacher Education, 61, 199-210.

Lapasta, L. (2018). Experiencias múltiples de apropiación del conocimiento para la construcción de la práctica profesional docente en la formación de profesores universitarios de ciencias exactas y naturales. Intenrational Journal Education and Teaching (PDVL), 1(1), 110-122. https://doi.org/10.31692/2595-2498.v1io1.19

Leblebicioglu, G., Metin, D., Yardimci, E. \& Berkyurek, I. (2011). Teaching the nature of science in the nature: A summer science camp. Elementary Education Online, 10(3), 1037-1055.

Logerwell, M. G. (2009). The effects of a summer science camp teaching experience on preservice elementary teachers' science teaching efficacy, science content knowledge, and understanding of the nature of science [Tesis de doctorado, George Mason University]. ProQuest Dissertations Publishing.

Luehmann, A. L. \& Markowitz, D. (2007). Science Teachers' Perceived Benefits of an Out-of-school Enrichment Programme: Identity needs and university affordances. International Journal of Science Education, 29(9), 1133-1161.

Marcelo, C. \& Vaillant, D. (2013). Desarrollo profesional docente. ¿Cómo se aprende a enseñar. ( $3^{\text {a }}$ ed.). Narcea.

Martínez, M. (2006). Validez y confiabilidad en la metodología cualitativa. Paradígma, 27(2), 733.

Medina, E., Castillo, J., Turizo L. \& Vega, A. (2019). Coaching en el aula: una estrategia parapotencializar las competencias personales de los estudiantes. Revista Estudios en Educación, 2(3),17-34. http://ojs.umc.cl/index.php/estudioseneducacion/index

Ministerio de Educación de Chile (2017). CPEIP Escucha a los Profesores. Para una lectura de las Consultas Participativas de Voces Docentes.

Ministerio de Educación (2020). Resultados Nacionales Evaluación Docente 2019. Ministerio de Educación. Centro de Perfeccionamiento, Experiementación e Investigaciones Pedagógicas (CPEIP).

Naizer, G., Bell, G.L., West, K. \& Chambers, S. (2003). Inquiry science professional development combined with a science summer camp for immediate application. Journal of Elementary Science Education, 15(2), 31-37.

Ortega, R. (2012). El coaching ontológico como estrategia para gerenciar el aprendizaje, gestionar el conocimiento, transformar los procesos educativos y potenciar cambios significativos. Sophia, Colección de Filosofía de La Educación, 13, 177-198. 
Peñaherrera, M., Cachón, J., \& Ortiz, A. (2014). La autoestima profesional docente y su implicación en el aula. Revista Magister, (26), 52-58

Pillen, M., Beijaard, D. \& Den Brok, P. (2013). Professional identity tensions of beginning teachers. Teachers and Teaching, 19(6), 66-678.

Pirrone, G. (2006). Los procesos identitarios en espacios de participación no tradicionales. Question, 11(1), 18-199.

Post-Zwicker, A. \& Guilbert, N. R. (1998). 'Plasma Camp': A Different Approach to Professional Development for Physics Teachers. Princeton Plasma Physics Laboratory (PPPL).

Qablan, A. M., Mansour, N., Alshamrani, S., Sabbah, S., \& Aldahmash, A. (2015). Ensuring effective impact of continuing professional development: Saudi science teachers' perspective. Eurasia Journal of Mathematics, Science and Technology Education, 11(3), 619-631.

Quintanilla, M., Izquierdo, M., \& Adúriz, A. (2014). Directrices epistemológicas para promover competencias de pensamiento científico en las aulas de ciencias. En M. Quintanilla (Ed.), Las competencias del pensamiento científico desde las emociones, sonidos y voces del aula (pp. 16-30). Bellaterra Ltda.

Quintanilla, M., Orellana, C., \& Páez, R. (2020). Representaciones epistemológicas sobre competencias de pensamiento científico de educadoras de párvulos en formación . Enseñanza de las Ciencias, 38(1), 47-66. https://doi.org/10.5565/rev/ensciencias.2714

Ruffinelli, A. (2016). Ley de desarrollo profesional docente en Chile: de la precarización sistemática a los logros, avances y desafíos pendientes para la profesionalización. Estudios Pedagógicos, 42(4), 261-279

Ruohotie-Lyhty, M. (2018). Chapter 3 Identity-Agency in progress: teachers authoring their identities. En P. Schutz, J. Hong \& D. Cross, Research on teacher identity: Mapping challanges and innovations (pp. 25-36). Springer.

Rushton, E. A., \& Reiss, M. J. (2020). Middle and high school science teacher identity considered through the lens of the social identity approach: a systematic review of the literature. Studies in Science Education, 1-63.

Schepens, A., Aelterman, A., \& Vlerick, P. (2009). Student teachers' professional identity formation: between being born as a teacher and becoming one. Educational Studies, 35(4), 36-378.

Schön, D. (1983). The reflective practitioner: how professionals think in action. Basic books.

Spector, B.S., Burkett, R. \& Leard, C. (2012). Derivation and implementation of a model teaching the nature of science using informal science education venues. Science Educator, 21(1), 5161.

Solbes, J., Fernández-Sánchez, J., Domínguez-Sales, M., Cantó, J., \& Guisasola, J. (2018). Influencia de la formación y la investigación didáctica del profesorado de ciencias sobre su práctica docente . Enseñanza de las ciencias, 36(1), 25-44 https://doi.org/10.5565/rev/ensciencias.2355

Swann, W. B., Jr., Chang-Schneider, C., \& Larsen McClarty, K. (2007). Do people's self-views matter? Self-concept and self-esteem in everyday life. American Psychologist, 62(2), 8494. https:/doi.org/10.1037/0003-066X.62.2.84

Tardif, M. (2010). Los saberes docentes y su desarrollo profesional. ( $3^{\mathrm{a}}$ ed.). Narcea.

Tesch, R. (1990). Qualitative research: Analysis types and software tools. Falmer.

Triviño, L. (2018). Principios metodológicos de la multimodalidad para la formación del profesorado de ciencias sociales. Revista de Investigación en Didáctica de las Ciencias Sociales (3), 71-86. DOI: https://doi.org/10.17398/2531-0968.03.71 
de Tezanos, A. (2012). ¿ Identidad y/o tradición docente?: apuntes para una discusión. Perspectiva Educacional, 51(1), 1-28.

Vaillant, D. (2019). Directivos y comunidades de aprendizaje docente: un campo en construcción. Revista Eletrônica de Educação, 13(1), 87-106. http://dx.doi.org/10.14244/198271993073

Vanegas, C. \& Fuantealba, A. (2019). Identidad profesional docente, reflexión y práctica pedagógica: Consideraciones claves para la formación de profesores. Perspectiva Educacional, 58(1), 115-138. DOI: https://doi.org/10.4151/07189729-Vol.58-Iss.1Art.780 115-138

Vezub, L. (2013). Hacia una pedagogía del desarrollo profesional docente. Modelos de formación continua y necesidades formativas de los profesores . Revista Páginas de Educación, 6(1), 97-124. http://paginasdeeducacion.ucu.edu.uy/inicio/item/43-pags_edu6.html

Volkmann, M. J. \& Anderson, M. A. (1998). Creating professional identity: Dilemmas and metaphors of a first-year chemistry teacher. Science Education, 82(3), 293-310.

Wallace, C.S. \& Brooks, L. (2014). Learning to teach elementary science in an experiential, informal context: Culture, learning, and identity. Science Education, 99, 174-198. 